\title{
Ambient air pollution and assessment of ozone creation potential for reactive volatile organic compounds in urban atmosphere of southwestern, Nigeria
}

\author{
Olumayede E. G. ${ }^{1 *}$ and Okuo J. M. ${ }^{2}$ \\ ${ }^{1}$ Department of Chemical Sciences, Faculty of Science, Ondo State University of Science and Technology, Okitipupa. \\ Ondo state, Nigeria. \\ ${ }^{2}$ Chemistry Department, University of Benin, Benin City. Edo State, Nigeria.
}

Accepted 1 August, 2013

\begin{abstract}
Volatile organic compound (VOC) species react at different rate and exhibit differences in reactivity with respect to ozone formation in polluted urban atmosphere. To assess this, the variations pattern, reactivity relative to $\mathrm{OH}$ radical and ozone creation potential of ambient VOCs were investigated in field studies at designated sites in urban centers of Akure and Ado-Ekiti, Southwestern, Nigeria, between June, 2009 and May, 2010. The ambient air samples were drawn into a tube using active sampling method with the low volume sampling pump (Acuro, Drager, Lubeck, Germany). The tube contains Chromosorb 106 as adsorbent. Air samples were collected four times per month at the height of $1.5 \mathrm{~m}$ from the ground surface so as to reflect the human breathing zone. On each sampling day, air samples were collected three times between $6.00 \mathrm{a} . \mathrm{m}$ and 7.00 p.m to reflect morning, afternoon and evening period. After sampling, the adsorbed VOCs were desorbed with carbon disulphide $\left(\mathrm{CS}_{2}\right)$ and the solution analyzed using gas chromatography coupled with mass spectrophotometer. Analysis of the VOCs data revealed that four major classes of abundant VOC groups were captured in the ambient air of the two studied centers. Among the four classes of abundant VOC groups, aromatic dominated with 61 to $77 \%$, followed by aliphatics (7 to $20 \%$ ), halogenated (5 to $21 \%$ ). The results reveal that the total VOCs at various sites showed significant $(p<0.05)$ diurnal pattern with bimodal peaks that followed the cycles of economic activities and traffic loads in the areas. The total ozone formation by abundant nonmethane hydrocarbons in this study were 52.54 and $71.53 \mu \mathrm{g} / \mathrm{m}^{3}$ at Akure and Ado-Ekiti, respectively with $\mathrm{m}, \mathrm{p}$-xylene, ethylbenzene being the lead contributors at both centres. The abundant alkane in the atmosphere calls for monitoring as they can be move farther distance from their sources and produce a higher concentration of ozone even though the local concentrations are very low.
\end{abstract}

Key words: Volatile organic compounds, photochemical reactive hydrocarbons, ozone formation potential.

\section{INTRODUCTION}

In recent years, it has become apparent that there are close links between climate change and tropospheric ozone. Ozone is the most important photochemical oxidant in the troposphere and holds a special position among the criteria pollutants and radiative trace gases found in the atmosphere. Ozone has been demonstrated equivocally to cause serious injury to sensitive species of vegetation (Ashmore, 1984; Skarby and Sellden, 1984). Clinical and epidemiological researches have also established that exposures to levels of ozone at, or even below the $120 \mathrm{ppb}$ level can produce significant changes in respiratory function in humans (McDonnell et al., 1983; 
Linn et al., 1986; Avol et al., 1984; Lippmann, 1989), therefore elevated concentration of ozone in the surface boundary layer will have lots of detrimental effects on human race and ecological environment.

Other peculiarity of ozone is not only because it is not released from either natural or anthropogenic sources but its tropospheric concentration has generally been rising. In the troposphere, ozone is transported downward from the stratosphere (Seinfeld and Pandis, 1998; Singh and Zimmermon, 1992). The mean annual ozone transport from stratosphere to troposphere is estimated at between 720 and 1220 million tones per annum (Vaughan, 1988). Another major source of ozone in the troposphere is that it is produced by photochemical reactions involving nitrogen oxides (NOx) and volatile organic compounds (VOCs), facilitated by sunlight (as shown in Equation 1) (Crutzen, 1974; Atkinson, 2000).

$\mathrm{VOC}+\mathrm{NO}_{\mathrm{x}}+$ sunlight $\rightarrow \mathrm{O}_{3}+$ other products

Other products in this reaction include gaseous peroxyl acetyl nitrate (PAN), nitric acid and oxygenated hydrocarbons.

Air pollution has become a problem in the main urban cities of the world, as energy demanded is increasing. Elevated levels of volatile organic compounds are known to be prevalent in the atmosphere of most world cities (Lee et al., 2002; Barletta et al., 2005; Srivastava et al, 2005; Srivastava, 2004, Na et al., 2001, 2003). In most of these studies, anthropogenic sources including motor vehicle exhaust and industrial emissions, power plants, gasoline vapors, chemical solvents, and vegetation are some of the major sources of VOCs (Srivastava et al, 2005; Lenicek et al., 1993; Sims and Overcash, 1983). High concentrations of photochemical reactive VOCs, such as olefins and aromatics, have been reported as well. These two groups have been identified as the main species responsible for ozone formation (Gasca et al., 2004; Mugica et al., 2002). Meanwhile, Sillman (1994) reported that ozone formation responds differently to different VOCs reactivity in different locations. In Nigeria, many researchers have addressed air pollution problem in the country cites (Baumback et al., 1995; Okuo and Ndiowokere, 2006; Ukepbor and Ahonkhia, 2000; Ukepbor et al., 2010; Obioh et al., 1994, Abdul-Raheem et al., 2008). Most of these researchers reported that emissions of large number of anthropogenic are known to be prevalent in the cities with vehicular emissions account up to $70 \%$ (Obioh et al., 1994) while some also showed significant temporal and spatial variations. Until the recent time, when we began the study of ambient volatile organic compounds, there has not been existing report on hydrocarbons concentrations and their variations characteristic in urban atmosphere of Nigerian cities (Olumayede, 2011; Olumayede and Okuo, 2012). The results from most of our studies showed atmospheric hydrocarbon levels of $30.64 \pm 8.40 ; 26.42 \pm 6.83$ and $24.16 \pm 3.62 \mu \mathrm{g} \cdot \mathrm{cm}^{-3}$ were observed in Benin City, Akure and Ado-Ekiti, respectively, with significant spatial and temporal patterns of distribution. The results also revealed the presence of photochemical reactive VOCs, including olefins and aromatics in the abundant VOCs composition. Unfortunately, the relative reactivity and contribution to production of ozone by these anthropogenic pollutants in Nigerian Cities has not been investigated.

The Southwestern Nigeria falls within the tropical rainforest region. The region has two distinct seasons (the long wet season and short dry season), the raining season between April and October, and the dry season between November and March. The temperature throughout the year ranges between 21 and $29^{\circ} \mathrm{C}$ except when it is extreme. Humidity is relatively high ranging between 50 and $90 \%$ depending on the season, while the rainfall ranges between 150 and $200 \mathrm{~mm}$ (NMA, 2009). Recently, there has been tremendous increase in the number of small-scale industries in most urban centers of this region. The small-scale industries are scattered all over the cities. Some of them are located within the premises of residential buildings. These small-scale indus-tries have their own characteristic pollutants, mostly VOCs, emitted to the atmosphere. It is therefore pertinent to quantify the relative contribution of the different atmospheric VOC species on photochemical cycle of ozone in the region.

The work presented in this paper is intended to provide data for better understanding of variability characteristics and relative reactivity of different abundant atmospheric VOC species within Akure and Ado-Ekiti, southwestern, Nigeria. The two centers used in this work are fast growing urban settlements in the Southwestern Nigeria. It is envisaged that the data generated would help to provide information on ozone formation potential of different captured VOC species in the areas and identify the potential threats to human health and natural ecosystem.

\section{METHODOLOGY}

\section{Sampling locations}

The present study was focused on Akure, Ondo State $\left(50^{\circ} .10^{\prime} \mathrm{N}\right.$ and $\left.7^{\circ} .15^{\prime} \mathrm{E}\right)$ and Ado Ekiti, Ekiti state $\left(5^{\circ} 13^{\prime} \mathrm{N}\right.$ and $\left.7^{\circ} 41^{\prime} \mathrm{E}\right)$. The population of Akure and Ado-Ekiti during 2006 national population census was estimated at about 360,268 and 313,690 people, respectively (NPC, 2010). They are both state administrative headquarters' and transitory towns, linked with other state capitals, both in the northern and southern parts of the country. In both centers, many small scales industrial plants in the town are located close to the residential areas such as liquid petroleum gas storage plants and most buildings have many ground level shops. Analysis of traffic in both centers revealed that the most predominant mode of transport in the metropolis were cars which constituted $71 \%$ of traffic.

\section{Ambient VOCs sampling and sampling routine}

The coordinate and description of the sampling locations for the 
collection of our data, sampling device, chemical extraction and analysis have been discussed in our previous work (Olumayede, 2008; Olumayede and Okuo, 2011).

Meteorological data, average monthly air temperature $\left({ }^{\circ} \mathrm{C}\right)$, relative humidity (\%), and wind speed $\left(\mathrm{ms}^{-1}\right)$ for the sampling period were measured simultaneously before and after VOCs measurements using a humidity/temperature meter, with resolutions of $0.1 \% \mathrm{RH}$ and $0.1^{\circ} \mathrm{C}$ (model RS 1364, RS components Ltd, UK). At the same time, wind speeds were measured using an LM -8000 anemometer with a resolution of $0.1 \mathrm{~ms}^{-1}$ (Heatmiser UK Ltd). The sampling period covers wet and dry seasons at different sites to highlight the temporal variability.

\section{Traffic survey}

A traffic count was performed during the sampling period on avenue close to each sampling site. The traffic data collected were analyzed for traffic composition, traffic volume and variation along the route. The hourly traffic volume was then determined.

\section{Chemical extraction and analysis}

After sampling, adsorption tubes were labeled and closed with special caps to avoid contamination and desorption (ASTM, 1988). Chemical extraction and analysis have been discussed in our previous work (Olumayede, 2008; Olumayede and Okuo, 2011).

\section{Quality control}

A quality assurance program was implemented in the framework of which all analytical systems related to the analysis of VOCs have been checked for their performance. Various quality control tools were used in order to ensure that adequate laboratory performance was maintained. These included control charts for standard solutions, analysis of control standards as unknown and analysis of the blank activated carbon tubes as process blank to determine if there was any contamination in the activated carbon tubes. None of the compounds included in this study were detected in $\mathrm{CS}_{2}$ and in process blanks. The calibration curve was found to show good linearity, with determination coefficients $\left(r^{2}\right)$ greater than 0.999 for all the compounds. The limits of detection for BTEX were determined for most VOCs using sample volume of $10 \mathrm{ml}$ and the values calculated in absolute mass. The limits of detection for carbonyls were found to be $0.1 \mathrm{mgm}^{-3}$ for acetone and $0.1 \mathrm{mg} \mathrm{m}^{-3}$ for benzene, toluene, ethyl benzene, $\mathrm{m}, \mathrm{p}$-xylene and $0.2 \mathrm{mgm}^{-3}$ for o-xylene.

\section{Statistical analysis}

In order to test the significance of the interaction between the mean total VOC obtained at different locations, two- way analysis of variance (ANOVA) statistical test was used.

\section{Estimation of ozone formation potential}

Recently, different methods are used to define the reactivity for ozone forming potential from non-methane hydrocarbon. In this study, the contribution individual VOC to ozone formation were also studied according to the propylene-equivalent concentration (Chameides et al., 1992) and maximum incremental reactivity (MIR) (Carter and Atkinson, 1989) methods.

Propylene-equivalent is a measure of the concentration of hydrocarbon on an $\mathrm{OH}$ - reactivity based scale normalized to the reactivity of propene. The propylene-equivalent is defined as:

Propylene-equivalent $=\mathrm{C}_{\mathrm{i}} \times \mathrm{K}_{\mathrm{OH}}(\mathrm{i}) / \mathrm{K}_{\mathrm{OH}}(\mathrm{C} 3 \mathrm{H} 6)$

Where $\mathrm{C}_{\mathrm{i}}$ is defined as a concentration of individual VOC species $\mathrm{K}_{\mathrm{OH}}$ (i) is the rate constant for the reactivity of individual VOC; and $\mathrm{K}_{\mathrm{OH}}\left(\mathrm{C}_{3} \mathrm{H} 6\right)$ is the rate constant for reaction of $\mathrm{C}_{3} \mathrm{H}_{6}$ with $\mathrm{OH}$ radical. The ozone formation potential is evaluated as product of the concentration of each VOC and the maximum incremental reactivity coefficient (MIR). The MIR is defined as:

OFP $_{(i)}=$ concentration $_{(i)} \times$ MIR coefficient ${ }_{(i)}$

Where, OFP (i) is defined as ozone formation potential of individual hydrocarbon $i$ and MIR coefficient; (i) the maximum incremental reactivity coefficient of compound $\mathrm{i}$, (Carter, 1994).

\section{RESULTS AND DISCUSSION}

\section{Distribution and mixing ratio of ambient VOC species in atmosphere of the sampling sites}

Ambient VOCs data for this study were the measured data generated between May, 2009 and June, 2010. In our previous report (Olumayede and Okuo, 2011), a total of 15 volatile organic compounds species were successfully identified and quantified in ambient air of Akure and Ado-Ekiti, among which were four alkanes, six aromatic compounds, three chlorinated hydrocarbons and two carbonyls. These compounds were used in this study.

The total concentration of VOCs was obtained by summing the concentrations of individual species detected. Figures 1 and 2 present the TVOCs distribution by compound type in the sampling sites of Akure and Ado-Ekiti, respectively.

In term of composition, the most abundant compound types in atmosphere of the two studied centers are: aromatic hydrocarbons, aliphatics, carbonyl and halogenated compounds. Aromatic accounted for between 61 and $77 \%$ in most sites; this was followed by aliphatics $20-7 \%$, while $5-21 \%$ halogenated compounds and carbonyl followed. A comparative study of TVOC in this study with similar urban centers earlier studied in Foshan, China (Tan et al., 2012), shows that the compositions of VOCs in Akure and Ado-Ekiti showed similarities with those of anthropogenic traffic impacted urban centers.

According to Sharif et al. (2008), factors responsible for diurnal variations of pollutants include (i) difference in local traffic volume at different times of the day (ii) traffic flow (iii) meteorological factors. In attempt to further identify how these factors affect pollution patterns in the study centers, we examined traffic and meteorological pattern in the centers.

The hourly traffic volume measured at the various sites (Tables 1 and 2) revealed significant spatial variation dependence of the economic activities around the sites. The market areas at the two studied centers have the highest traffic volume. This is expected as it is common in 


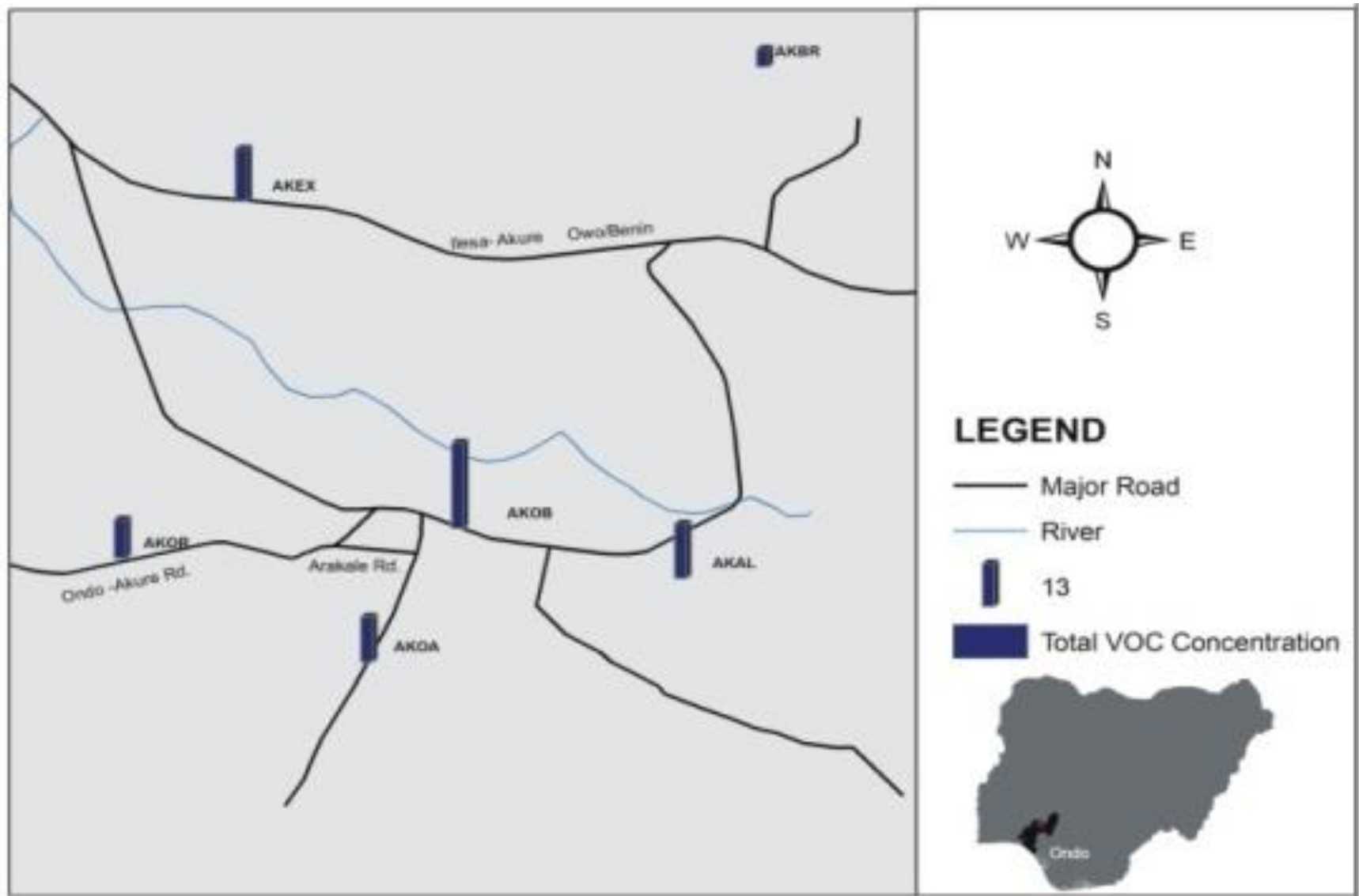

Figure 1. Map of Akure showing the TVOCs at the various sampling sites.

Table 1. Monitoring locations, their characteristics and co-ordinates at Akure.

\begin{tabular}{|c|c|c|c|c|}
\hline Site & Code & Coordinate & Site description & $\begin{array}{l}\text { Hourly Traffic } \\
\text { volume (Vph) }\end{array}$ \\
\hline 1 & AKLR & $\begin{array}{l}N^{\circ} 07 \quad 17^{\prime}, 06.2^{\prime} \\
\mathrm{E} 005^{\circ} 10^{\prime} 34.0^{\prime}\end{array}$ & $\begin{array}{l}\text { Created along llesa- Akure- Owo/Benin road, an express way and } \\
\text { close to the NNPC station. }\end{array}$ & 682 \\
\hline 2 & AKOR & 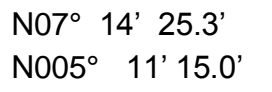 & $\begin{array}{l}\text { Oke - Aro monitoring site, a residential area with many local buildings } \\
\text { and close to furniture workshops. }\end{array}$ & 986 \\
\hline 3 & AKOB & $\begin{array}{l}\text { N07' } 15^{\prime} 12.7^{\prime} \\
\mathrm{E}^{\prime} 5^{\circ} 11^{\prime} 43.8^{\prime \prime}=\end{array}$ & Created at the Oja Oba, a market square with heavy traffic. & 1758 \\
\hline 4 & AKAL & $\begin{array}{l}\text { N07 } 14^{\prime} 55.1^{\prime} \\
\mathrm{E} 005^{\circ} 12^{\prime} 54.4^{\prime}\end{array}$ & Alagbaka monitoring site, the site of many government offices. & 986 \\
\hline 5 & AKOD & 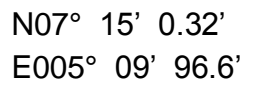 & $\begin{array}{l}\text { Ondo road park monitoring site, a bus terminus with a cluster of petrol } \\
\text { dispensing stations. }\end{array}$ & 563 \\
\hline 6 & AKBR & 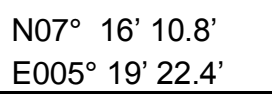 & $\begin{array}{l}\text { Aponmu monitoring site, a small community and a background site for } \\
\text { the study. }\end{array}$ & 1 \\
\hline
\end{tabular}

Nigerian cities to have the market located around the bus stops.

In Nigeria, it is customary to classify the day into three time zones- morning (from dawn to noon), afternoon (noon to 4:00 pm) and evening (4:00 pm to 7:00 pm). Figure $3 a$ and $b$ present the diurnal distribution of the
TVOCs in each sampling site. A cursory look at these figures revealed that the distribution showed bimodal pattern with morning and evening peaks in most sampling sites of both centers. Emissions from vehicle traffic begin around $6.00 \mathrm{a} . \mathrm{m}$ and stay till $9.00 \mathrm{a} . \mathrm{m}$. This is followed by various degrees of decrease in the afternoon and 
Table 2. Monitoring locations, their characteristics and co-ordinates at Ado-Ekiti.

\begin{tabular}{|c|c|c|c|c|}
\hline Site & Code & Coordinate & Site description & $\begin{array}{l}\text { Hourly traffic } \\
\text { volume (Vph) }\end{array}$ \\
\hline 1 & ADOM & 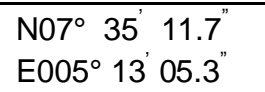 & $\begin{array}{l}\text { Created along lkere road, close to a furniture factory and Coca-cola Depot. The } \\
\text { roadway carries large traffic volume daily. }\end{array}$ & 662 \\
\hline 2 & $A D O G$ & $\begin{array}{l}\mathrm{N}^{0} 7^{\circ} 37^{\prime} 30.1^{\prime \prime} \\
\mathrm{N}^{\prime \prime} 5^{\circ} \quad 133^{\prime} 13.2^{\prime \prime}\end{array}$ & $\begin{array}{l}\text { Created at Oba Market/old garage. Sources situate within close proximity are } \\
\text { dump site, petroleum dispensing stations, wholesaling and large traffic volume. }\end{array}$ & 1183 \\
\hline 3 & ADFP & $\begin{array}{l}\text { N07 } 37^{\prime} 51.3^{\prime \prime} \\
\mathrm{E}^{\prime \prime} 5^{\circ} 13^{\prime} 52.3^{\prime \prime}\end{array}$ & $\begin{array}{l}\text { Fajuyi Park monitoring site is characterized by many roads intersection with } \\
\text { large traffic volume. }\end{array}$ & 860 \\
\hline 4 & ADIL & $\begin{array}{l}\text { N07 } 38^{\circ} 16.7^{\prime \prime} \\
\mathrm{E}^{\prime \prime}\end{array}$ & $\begin{array}{l}\text { Created at the state secretariat, where many government offices are situated, } \\
\text { the roadway carries large traffic volume. }\end{array}$ & 611 \\
\hline 5 & ADAD & $\begin{array}{l}\text { N07 } 40^{\circ} 41.1^{\prime \prime} \\
{\mathrm{E} 005^{\circ}}^{\prime} 14^{\prime} 39.2^{\prime \prime}\end{array}$ & $\begin{array}{l}\text { Adehun monitoring site close to Hotel and the Petroleum Depot. The road leads } \\
\text { to the University; hence the roadway carries large traffic volume daily. }\end{array}$ & 713 \\
\hline 6 & ADOD & $\begin{array}{l}\mathrm{N}_{07}^{\circ} 36^{\prime} 76.7^{\prime \prime} \\
\mathrm{E} 005^{\circ} 07^{\prime} 83.7^{\prime \prime}\end{array}$ & Odo camp site, a background/control site & 3 \\
\hline
\end{tabular}
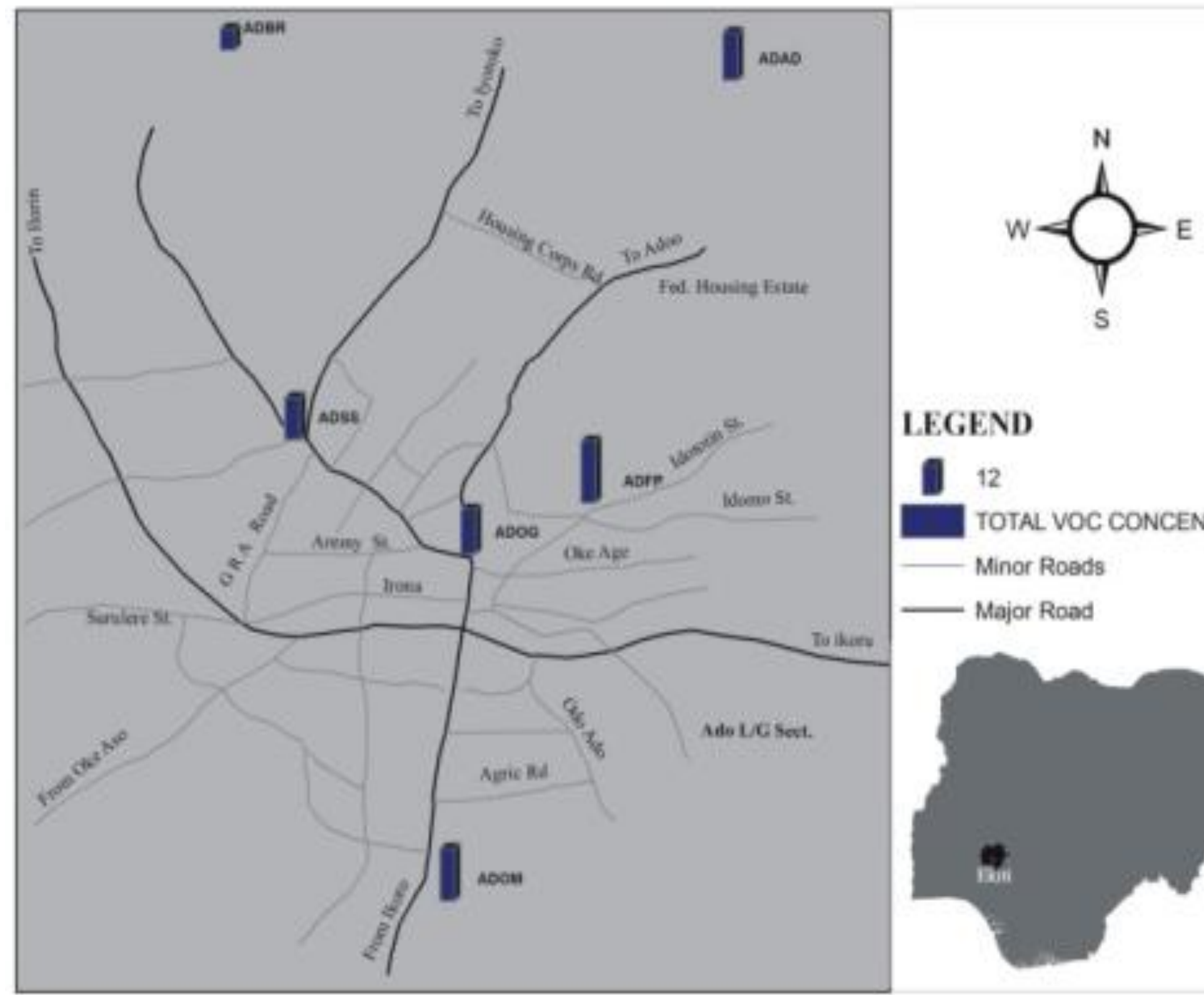

\section{LEGEND}
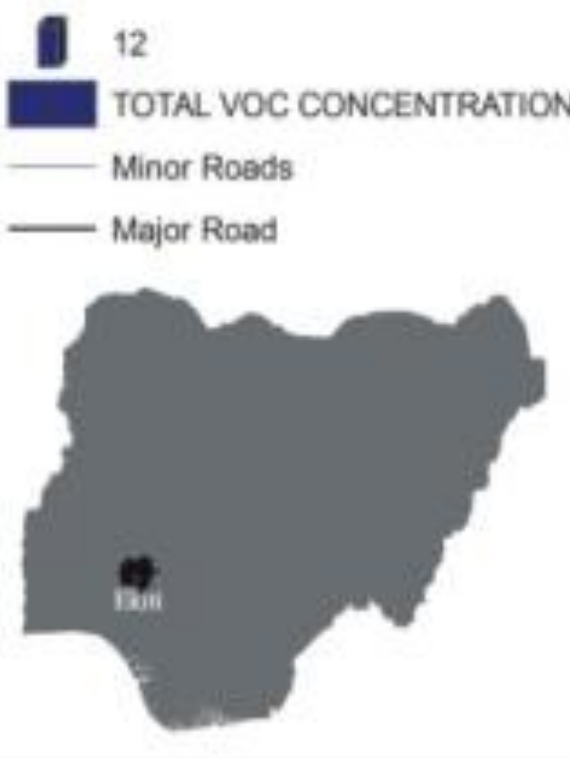

Figure 2. Map of Ado-Ekiti showing the TVOCs at the various sampling sites. 

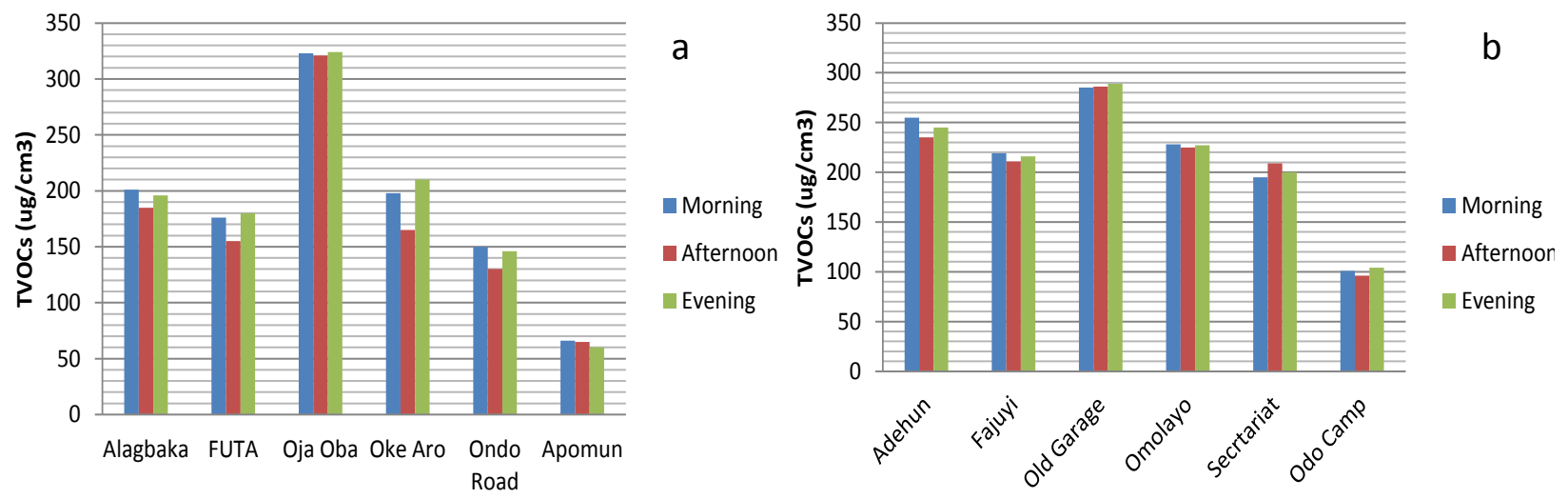

Figure 3a. Diurnal Pattern of TVOCs in Akure sampling site. b. Diurnal Pattern of TVOCs in Ado-Ekiti sampling sites.
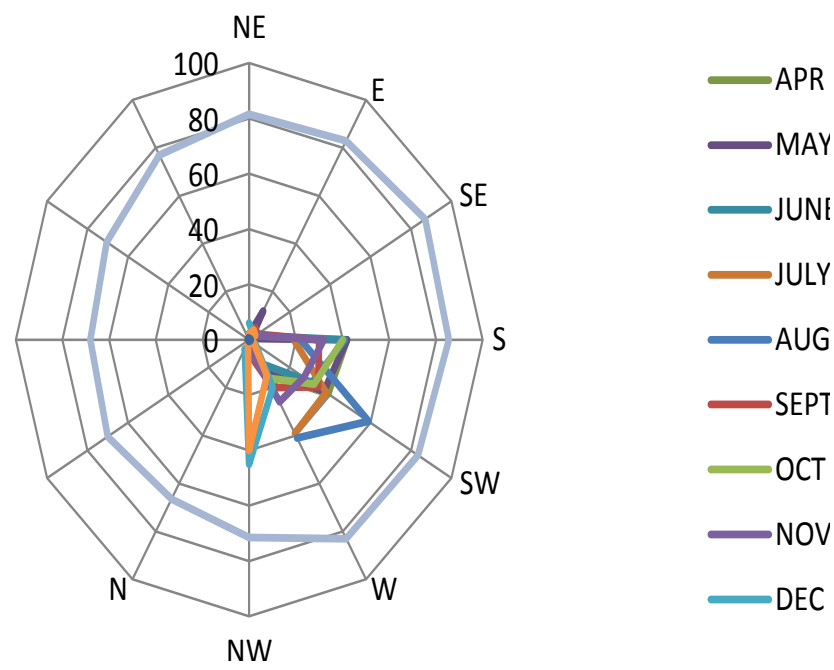

Figure 4a. Wind direction rose in Akure during the sampling period.
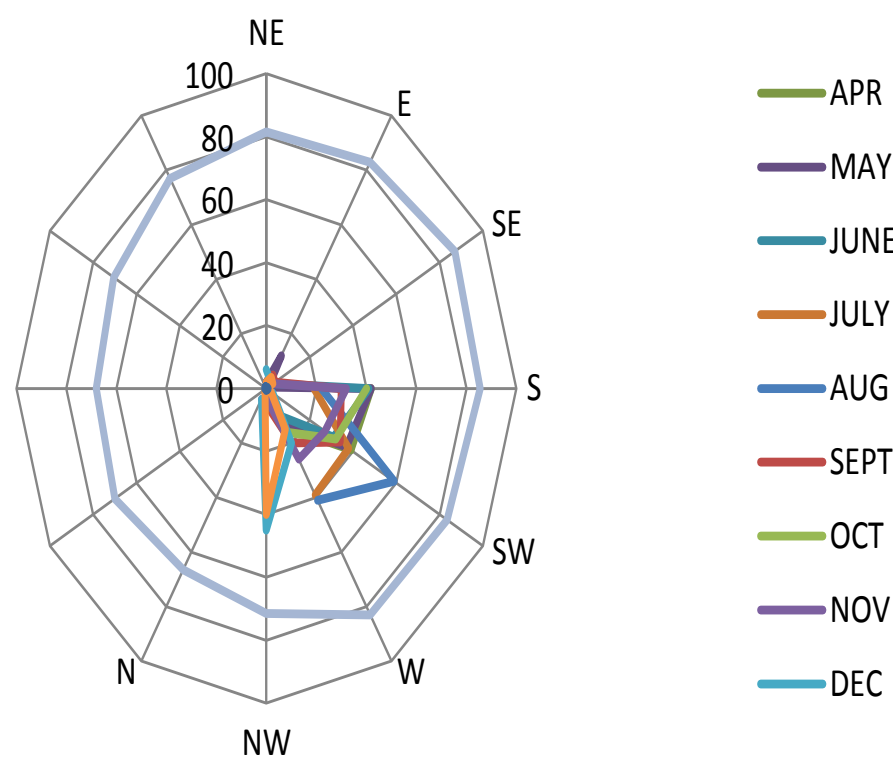

JULY

AUG

-SEPT

OCT

NOV

$\longrightarrow$ DEC

increase in the evening. The early morning period coincide with the hours of maximum traffic volume as a result of the rush to get to the offices, schools and the city markets. The early morning rush can further be attributed to frequent traffic jams resulting from high traffic density, poor road network, poorly maintained road, poor traffic handling and inadequate traffic disciplines. The observed slight uniformity at Oja-Oba and Old garage at Akure and Ado-Ekiti respectively may be attributed to uniformity in traffic volume as the sites are located around market and bus stops.

The same reason has been deduced for similar observation for other pollutants in previous studies (Ukpebor et al., 2010; Baumbach et al., 1995). Meanwhile, the deviation observed at sites close to government offices (Alagbaka site and Secretariat site of Akure and Ado-Ekiti centres, respectively), TVOC concentrations have a distinctive feature with the peak occurring at the afternoon. This suggests the possibility of contributions from sources other than vehicular emission. These sources may include emission from uses of various gargets such as air-conditioning, photocopies, lamination machines, etc. are common. The activities in the area take place mostly during afternoon.

In order to investigate the influence meteorological conditions on the distribution of TVOCs, we determined the monthly weighted-average in each site along with the frequencies of wind speeds and the wind direction rose in the studied centers as presented in Figure $4 \mathrm{a}$ and b. We also determine the specific site monthly weightedaverage in each sampling sites (Figures $5 a$ and b). In Nigeria, wet season includes June, July, August, September and October while dry season includes November, December, January, February, March and April. The most frequency wind direction was the southsouthwest (S-SW) wind during the wet months while the NW wind dominates during the dry months.

In our results, we observed that the TVOC values were lower when the wind speed and relative humidity were high. Figures revealed very calm wind speeds during dry season months. Meanwhile, De Foy et al. (2005) reported

Figure $\mathbf{4 b}$. Wind rose in Ado-Ekiti during the sampling period. 


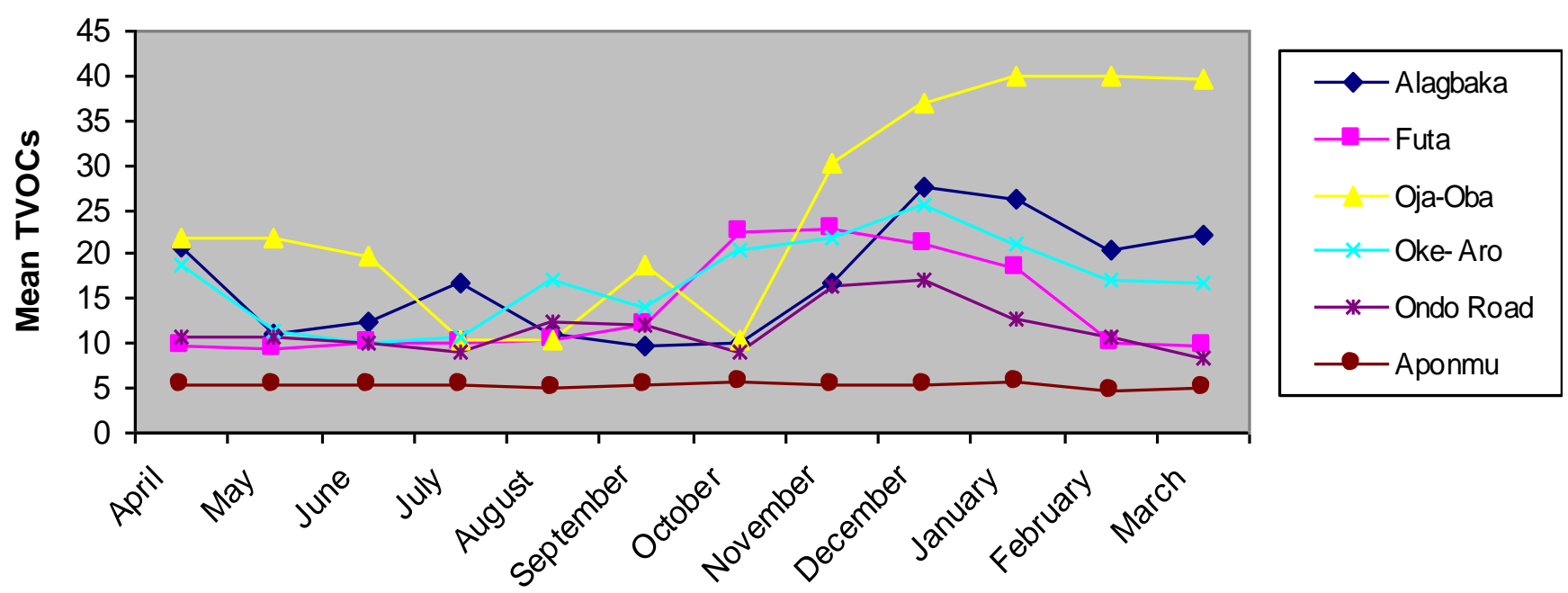

Figure 5a. Monthly average TVOCs at the various sampling sites of Akure.

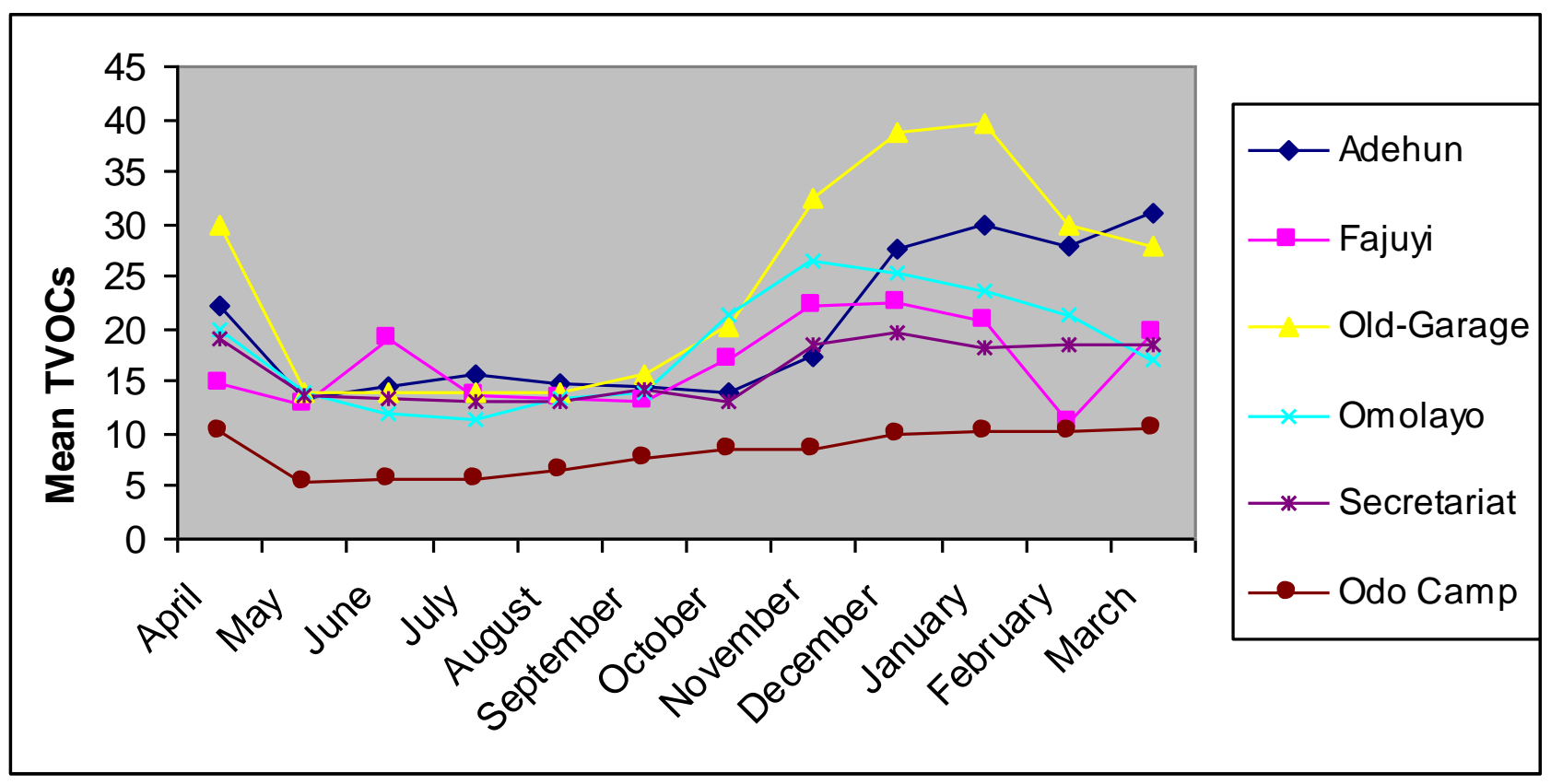

Figure 5b. Monthly average TVOCs at the various sampling sites of Ado-Ekiti.

that winds are always calm at sunset leading to minimal horizontal dispersion. The observations in this study agree well with earlier reports that low wind speed is responsible for poor dispersion and dilution of pollutants in Benin City, Nigeria (Ukpebor et al., 2010; Olumayede et al., 2012).

In general, pollutant emissions follow the cycles of human activity and traffic load with rises near the start of each day's activities, followed by various degrees of decrease or increase around midday, increases in early evening and declines late in night. Such traffic load activity obviously depends on various characteristics of meteorological factors.

\section{Mixing ratio and ozone formation potential}

Table 3 summarizes the mean, standard deviation of individual abundant VOC species at Akure and Ado-Ekiti. The species considered for analysis accounted for about $90 \%$ of the total VOCs. On the basis of average concentrations, the most abundant VOCs at Akure were in decreasing order; ethylbenzene ( $3.76 \pm 0.21)$; benzene 
Table 3. Concentration, reactivity and ozone formation potential of measured non-methane hydrocarbons at Akure and Ado-Ekiti.

\begin{tabular}{|c|c|c|c|c|c|c|c|c|c|c|}
\hline VOC species & Group & $\mathbf{k}_{\mathrm{OH}}$ & $\begin{array}{c}\text { Akure Mean } \\
\pm S D\end{array}$ & $\begin{array}{c}\mathrm{OH} \\
\text { reactivity }\end{array}$ & $\begin{array}{l}\text { Prop- } \\
\text { equiv }\end{array}$ & OFP & $\begin{array}{c}\text { Ado-Ekiti } \\
\text { Mean } \pm \text { SD }\end{array}$ & $\begin{array}{c}\mathrm{OH} \\
\text { reactivity }\end{array}$ & $\begin{array}{l}\text { Prop- } \\
\text { equiv }\end{array}$ & OFP \\
\hline n-Butane & \multirow{5}{*}{ Aliphatic } & 2.54 & $0.34 \pm 0.03$ & 0.86 & 0.03 & 0.37 & $0.33 \pm 0.08$ & 0.84 & 0.03 & 0.36 \\
\hline 2,2-Dimethylbutane & & 2.59 & $0.37 \pm 0.05$ & 0.96 & 0.04 & 0.41 & $1.53 \pm 0.12$ & 3.96 & 0.15 & 1.70 \\
\hline Isopentane & & 5.6 & $0.35 \pm 0.07$ & 1.96 & 0.08 & 0.48 & $0.69 \pm 0.04$ & 3.86 & 0.15 & 0.94 \\
\hline 3-Methylpentane & & 3.7 & $0.35 \pm 0.10$ & 1.30 & 0.05 & 0.60 & $0.17 \pm 0.01$ & 0.63 & 0.02 & 0.29 \\
\hline Undecane & & 11.2 & $2.36 \pm 0.74$ & 26.43 & 1.01 & 1.30 & $2.06 \pm 0.03$ & 23.07 & 0.88 & 1.13 \\
\hline Benzene & \multirow{6}{*}{ Aromatic } & 1.23 & $2.36 \pm 0.22$ & 2.90 & 0.11 & 1.63 & $2.23 \pm 0.16$ & 2.74 & 0.1 & 1.54 \\
\hline Toluene & & 5.96 & $2.06 \pm 0.51$ & 12.28 & 0.47 & 7.99 & $2.03 \pm 0.18$ & 12.10 & 0.46 & 7.88 \\
\hline Ethylbenzene & & 7.1 & $3.76 \pm 0.21$ & 26.70 & 1.02 & 11.02 & $2.21 \pm 0.31$ & 15.69 & 0.6 & 6.48 \\
\hline m,p-Xylene & & 19 & $1.69 \pm 0.09$ & 32.11 & 1.22 & 25.7 & $2.42 \pm 0.56$ & 45.98 & 1.74 & 36.81 \\
\hline o-xylene & & 13.7 & $0.52 \pm 0.14$ & 7.12 & 0.27 & 3.87 & $1.44 \pm 0.17$ & 19.73 & 0.75 & 10.71 \\
\hline Napthalene & & NA & $0.06 \pm 0.01$ & - & - & 0.19 & $0.05 \pm 0.01$ & - & - & 0.16 \\
\hline Methylene Chloride & \multirow{3}{*}{ Halogenated } & NA & $0.16 \pm 0.01$ & - & - & 0.01 & $0.31 \pm 0.11$ & - & - & 0.01 \\
\hline Carbon tetrachloride & & NA & $0.26 \pm 0.05$ & - & - & 0 & $0.16 \pm 0.04$ & - & - & 0 \\
\hline Chloroform & & NA & $0.23 \pm 0.16$ & - & - & 0.01 & $0.13 \pm 0.02$ & - & - & 0.00 \\
\hline Ethylacetate & \multirow{2}{*}{ Carbonyl } & NA & $0.11 \pm 0.02$ & - & - & 0.41 & $0.71 \pm 0.13$ & - & - & 0.42 \\
\hline Acetone & & NA & $0.42 \pm 0.03$ & - & - & 0.18 & $0.28 \pm 0.04$ & - & - & 0.10 \\
\hline
\end{tabular}

${ }^{*} \mathrm{~K}_{\mathrm{OH}}$ corresponds to the reaction rate coefficient $\left(\mathrm{cm}^{3}\right.$ molecule $\left.{ }^{-1} \mathrm{~s}^{-1}\right) \times 10^{-12}$ published by Atkinson $(1994,1997)$; OH reactivity $=$ Product of mean individual VOC concentration and $\mathrm{OH}$ reaction rate coefficient.

$(2.36 \pm 0.22)$; undecane $(2.36 \pm 0.74)$, toluene $(2.06 \pm$ 0.51), m,p-Xylene (1.69 \pm 0.09); ethylacetate $(0.11 \pm$ $0.02)$ and the lowest being napthelene $(0.05 \pm 0.02)$. At Ado-Ekiti, the order was m,p-Xylene (2.42 \pm 0.56$)$; benzene (2.23 \pm 0.16$)$; ethylbenzene (2.21 \pm 0.31$)$; undecane $(2.36 \pm 0.74)$, toluene $(2.06 \pm 0.51)$, and the lowest being napthelene $(0.06 \pm 0.01)$. Similar trend had been observed in other studied (Barletta et al., 2008; Tang et al., 2007) but with different order. A comparison of the mixing ratios in our study with other cities previously studied revealed that value in Akure and AdoEkiti are lower. This may be attributed to difference in population of the cities.

The actual amount of ozone produced by a given hydrocarbon depends on their particular oxidation mechanism and their abundance (Carter, 1994). One of the objectives of this study was to examine the relative importance of the abundant atmospheric hydrocarbon compounds for their potential role in the production of ozone. For this purpose, we estimated the reactivity of the abundant hydrocarbon with hydroxyl radical $(\mathrm{OH})$ in each studied centre, which represents the contribution of each species to the OH lost rate (Atkinson, 1994).

Table 3 lists the major hydrocarbons in the atmosphere of the studied centers by their annual mean concentrations along with their reactivity relative to $\mathrm{OH}$ radical. In our study, the result shows that ranking by propylequivalent, the alkanes included in this study; butane, isopentane, methylpentane and methylhexane account for $58 \%$ of the total propyl- equivalent concentration. It is important to point out that many oxygenated and halogenated VOCs were not considered in our analysis, due to absence of the $\mathrm{K}_{\mathrm{OH}}$ values; therefore, we considered that it is appropriate to use the term non-methane hydrocarbons.

The total ozone creation potential in the two centres of our study was 52.54 and $71.53 \mu \mathrm{g} / \mathrm{m}^{3}$ at Akure and AdoEkiti respectively. At Akure, the highest photochemical $\mathrm{O}_{3}$ formation of $25.70 \mu \mathrm{g} / \mathrm{m}^{3}$ comes from m,p-xylene. This is followed in the decreasing order by ethylbenzene $(11.02$ $\left.\mu \mathrm{g} / \mathrm{m}^{3}\right)$, toluene $\left(7.99 \mu \mathrm{g} / \mathrm{m}^{3}\right)$, o-xylene $\left(3.87 \mu \mathrm{g} / \mathrm{m}^{3}\right)$. Similar trend was observed at Ado-Ekiti centre with $\mathrm{m}, \mathrm{p}$ xylene $\left(36.81 \mu \mathrm{g} / \mathrm{m}^{3}\right)$, toluene $\left(7.88 \mu \mathrm{g} / \mathrm{m}^{3}\right)$, ethylbenzene $\left(6.48 \mu \mathrm{g} / \mathrm{m}^{3}\right)$. These results indicate that aromatics played the most significant role in $\mathrm{O}_{3}$ formation in the studied centers. So and Wang (2004) also found that $\mathrm{m}, \mathrm{p}$-xylene and toluene were ranked high in ozone formation in urban Hong kong where the reactivity of VOC was dominated by anthropogenic sources. The fact that undecene and 22-dimethylbutane, aliphatic group and heavy hydrocarbon were ranked among the highest contributions to ozone formation in our study suggested that pollutants associated with diesel combustion and exhaust from generators need to be monitored in the area. These alkanes have longer lifetimes and can be transported farther from their sources hence they can produce a higher concentration of ozone even though the local concentrations are very low.

A comparison of total ozone formation potential (OFP) in our study with results from other cities of the world revealed that the total concentration of ozone production in our study is 12 fold lower than the value of $863.4 \mu \mathrm{g} / \mathrm{m}^{3}$ 
reported in Foshan, China (Tan et al., 2012).

\section{Conclusions}

The VOC concentrations in ambient air of two Nigerian urban centers of Akure and Ado-Ekiti were studied to understand the distribution patterns. The diurnal trend of TVOCs concentrations showed bimodal peaks with morning and evening peaks which followed the traffic pattern of the study centers and suggest the importance of vehicular emission. The prevalence of low wind speed in the studied centers was also observed to be responsible for the poor dilution and dispersion of the emitted VOCs. Evaluation of ozone formation potentials of the four classes of hydrocarbons detected showed that aromatics play important roles in ozone formation in the centres.

\section{REFERENCES}

Abdul-Raheem AMO, Adekola FA, Obioh IO (2008) The seasonal variation of Sulphur dioxide and Nitrogen Oxides in Two Nigerian Cities. Environ. Model. Assess. DOI10.1007/s10666-008-9142-x.

Ashmore MR (1984). Effects of ozone on vegetation in United Kingdom. In: the evaluation and assessment of the effects of photochemical oxidants on Human Health, Agricultural crops, forestry, material and visibility. P, Grennfelt, edition (Swedish Environmental Research Institute, Goteborg). pp. $92-104$.

ASTM (1988). Method D 3686- 84: Standard practice for sampling atmospheres to collect organic compound vapours. Annual book of ASTM standards 11(03): 234-240.

Atkinson R (1997). Gas-phase Tropospheric Chemistry of Volatile Organic Compounds: 1. Alkanes and Alkenes. J. Phys. Chem. Ref. Data 26: 215-290.

Atkinson R (2000).Atmospheric Chemistry of VOCs and NOx. Atmos. Environ. 34: 2063-2101.

Barletta B, Meinardi S, Rowland FS, Chan CY, Wang XM, Zou XC, Chan LY, Blake DR (2005). Volatile Organic Compounds in 43 Chinese Cities. Atmos. Environ. 39: 5979-5990.

Carter WPL (1994), Development of ozone reactivity scales for volatile organic compound. J. Air Waste Manage. Assoc. 44:881-889

Carter WPL, Atkinson R (1989). Computer modeling study of incremental hydrocarbon reactivity. Environ. Sci. Technol. 23:864880.

Chameides WL, Fehsenfeld F, Rodgers MO, Cardelino C, Matinez J, Parrish D, Lonnemans W, Lawson DR, Rasmussen RA, Zimmerman P, Greenberg J, Middleton P, Wang T(1992). Ozone precursor relationships in the ambient atmosphere. J. Geophys. Res. 97(D5):6037-6055.

Crusten JP (1974). Photochemical reactions initiated by and influencing ozone in unpolluted tropospheric air. Tellus 26:47-57

De Foy B, Caetano E, Magana V, Zitacuaro A, Cardenas B, Retama A, Ramos R, Molina LT, Molina MJ (2005) Mexico City basin wind circulation during MCMA-2003 field campaign. Atmos. Chem. Phys. 5: 2267 - 2288.

Lee SC, Chiu KF, Zou SC, Wang Xinming (2002). Volatile Organic Compounds(VOCS) in Urban atmosphere of Hong Kong. Chemosphere 48:375-382.

Lenicek J, Sekyra M, Panmdey P, Citkova M, Benes I, Novotna J, Koclanova S, Helaskova J, Sinonva M (1993). Polycyclic Aromatic Hydrocarbons at program Teplice Site in the Czech Republic, Toxicol. Environ. Chem. 58:25.

$\mathrm{Na} \mathrm{K}$, Kim YP, Moon K (2003). Diurnal Characteristics of Volatile Organic Compounds in the Seoul Atmosphere. Atmos. Environ. 37:733-742.
Na K, Kim YP, Moon KC, Moon I, Fung K (2001). Concentrations of Volatile Organic Compounds in an Industrial Area of Korea. Atmos. Environ. 35: 2747-2756.

NMA (2009). Nigerian Meteorological Agency, Weather Report Bulletin.

Obioh IB, Oluwole AF, Akeredolu FA (1994) Lead Emissions and Source Strength In Nigeria: 1998 Inventory in Heavy Metals in The Environment. Allen and Nriagu (eds). Proceeding of an international conference, Toronto Canada, 12 -17 september1993 CEP Publishers ISBN 0-905941-51-9, 271-274

Okuo JM, Ndiokwere CL (2006) Elemental characterization of total suspended particulate matter in an urban: A case of Benin City, Nigeria. J. Chem. Soc. Niger. 31 (1\&2): 6 - 11

Olumayede EG, Okuo JM (2011) Baseline Levels Of Volatile Organic Compounds In Atmosphere Of Two Urban Centres Of Southwestern, Nigeria Intern. J. Chem. Sci. 4(1):42-55.

Olumayede EG (2011). Characterizations, source identification and apportionment of volatile organic compounds in atmosphere of three Nigerian urban centres, Unpublished Ph.D thesis, University of Benin, Edo, Nigeria.

Olumayede EG, OkuoJM (2012). Variation Characteristics Of Volatile Organic compounds in an Urban Atmosphere in Nigeria Polish $\mathrm{J}$. Environ. Stud. 21:177-186.

Seinfeld, J.H.,and Pandis S.N. (1998): Atmospheric chemistry and Physics: From Air pollution to climate change. Willey, New York, NY, pp 234-336.

Sharif TA, El-Henshir AK, Treban MM (2008). Variations of Air pollution with related meteorological factors in Tripoli (Case study); Air Pollution XVI; Edited by C.A. Brebbia, J.N.S Longhurst.

Sillman $\mathrm{S}$ (1994). The use of $\mathrm{NO}_{x}, \mathrm{H}_{2} \mathrm{O}_{2}$ and $\mathrm{HNO}_{3}$ as indicators for ozone-NOx hydrocarbon sensitivity in urban locations. J. Geophys. Res. 100:14175-14188.

Sims RC, Overcash MR (1983). Polycyclic Aromatic Hydrocarbons (PANs) in soil - plant system. Residue Rev. 88: 1.

Singh, H.B and Zimmermon, P.B. (1992); Edited by O.Nriagu, Wiley Services On Advance In Environment Science And Technology 24, 177.

Skarby L, Sellden LR (1984). The effects of ozone on crops and forests. Ambio 13:68 - 72 .

So $\mathrm{KL}$, Wang $\mathrm{T}$ (2004). $\mathrm{C}_{3}-\mathrm{C}_{12}$ Non methane hydrocarbons in subtropical Hong kong: Spatial- Temporal Variations, Source Receptor Relationship and Photochemical Reactivity. Sci. Total Environ. 328:161-174

Srivastava A (2004). Source Apportionment of Ambient Volatile Organic Compounds in Mumbia City. Atmos. Environ. 38 (39):6829 - 6843.

Srivastava, A.; Joseph; A. E., More, A. and Patil, S., (2005), Emissions of VOCs at Urban Petrol Retail Distribution Centres in India (Delhi and Mumbia), Environmental Monitoring and Assessment 109(13):227- 242.

Tan JH, Guo SJ, Ma YL, Yang FM, He KB, Yu YC, Wang JW, Shi ZB, Chen GC (2012). Non-methane Hydrocarbons and their Ozone formation potentials in Foshan. Aerosol Air Qual. Res. 12:387-398.

Ukpebor EE, Ukpebor JE, Eremonene F, Odiase JI, Okoro D (2010). Spatial and Diurnal variation of Carbon monoxide pollution from Motor Vehicles in an Urban Centre. Pol. J. Environ. Stud. 19 (4): $817-$ 823.

Vaughan G (1988). Stratosphere-Troposphere Exchange of ozone: "In troposheric interactions", lasken, I.S.A (edition), NATO ASI Series C, Volume 227; Reidel Publishing Company, Dordrecht, Holland. pp. 125-135. 